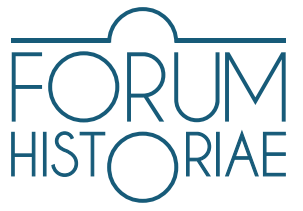

\title{
Conspiracy Theories and Rumours as Key Elements of Political Propaganda: The Cold War in the USA and Czechoslovakia in the 1950s
}

\author{
Zuzana Panczová
}

\begin{abstract}
PANCZOVÁ, Zuzana. Conspiracy Theories and Rumours as Key Elements of Political Propaganda: The Cold War in the USA and Czechoslovakia in the 1950s.

Rumours and hearsay can be important communication devices in civil society. Their influence tends to intensify in times of social crises and long-term conflict, which then can function as a test of trust in official authorities. The Cold War took place in an almost apocalyptic atmosphere fearing the outbreak of a fatal nuclear conflict. On both sides, combat was waged not only in the fields of armaments, economics or technology, but also on a psychological level, as a way to gain the trust and sympathy of citizens. The dividing line between East and West was also a demarcation between two frequently mirrored images of the enemy presented by representatives of state power and the state-controlled media. However, in contrast to official propaganda, there was also a less manageable spontaneous public debate, which responded to the intervention of state supervision, questioned official interpretations and sought its own answers to important social events. In this paper, the function of rumours and conspiracy theories during the Cold War is described on both sides of the conflict, as indicators of public opinion and as tools for influencing it. The "potato beetle" case and narratives about an alleged communist conspiracy in the USA during the period of "McCarthyism" became symbols of the conspiratorial rhetoric of the Cold War. The article also serves as a starting point for reflections on the differences in the spread of political rumours in totalitarian and democratic societies.
\end{abstract}

Keywords: rumours, conspiracy theories, trust, Cold War, propaganda, censorship, ideology, public opinion DOI: https://doi.org/10.31577/forhist.2021.15.2.3

\section{Introduction}

mong personal relationships, trust is usually built through a series of positive ex-

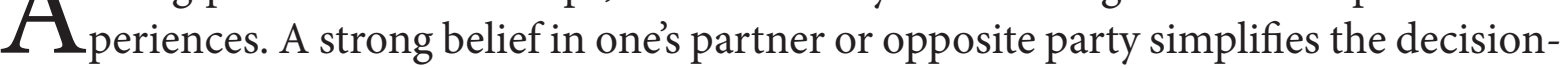
-making process and helps to temper or prevent conflict. From a larger perspective, the level of large groups or whole societies, we can talk about trust and distrust in several contexts, one being faith in official institutions or the authorities of state power. An authority that does not have sufficient trust of its citizens must base its legitimacy on a restrictive and coercive means of rule, otherwise it risks collapse. Alongside traditional time dependant or content-restricted methods populations usually employ to express trust in their governments and policies (elections, referendums, opinion polls), rumours are among the oldest informal channels, invading communication lanes and contaminating social trust.

Rumours and hearsay exist in a broad spectrum of what is covered by the "proposi-

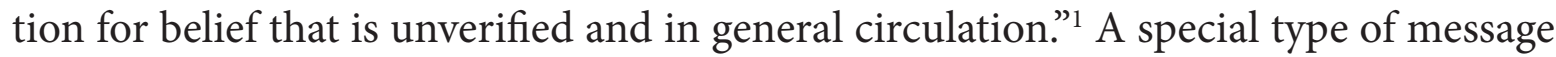

The research used in this article was supported by the project VEGA Folklore, folkloristics and ideology nr. 2/0107/19.

1 ROSNOW, Ralph L. Psychology of Rumor Reconsidered. In Psychological Bulletin, 1980, Vol. 87, No. 3 , p. 582. 
conveyance similar to the rumour is the so-called conspiracy theory, which is related not so much in form as in content; replete with unverified information about dangerous conspiracies. Conspiracy theories can be thought of as a subgroup of rumours with similar subjects and the fact that categorical judgments cannot be made about the truth or accuracy of the information, claims or beliefs, is typical. In common language as well as in contemporary journalist jargon, the labels "rumour" and "conspiracy theory" predominantly evoke thoughts of lies, disinformation or nonsense. The very nature of a conspiracy theory suggests that certain competencies and resources that not everyone has at their disposal are necessary to actually uncover the plot. The majority of such tales can be considered misinformation due to the inherent ideological bias, inconsistency of judgments, lack of reality in the views, ${ }^{2}$ and so on. Despite frequent factual inconsistencies, however, rumours and conspiracy theories are a valuable tool in understanding a group's collectively shared emotions, apprehensions, fears and desires. The gossip can be seen as a symbolic expression of trust or distrust towards the social system and its institutions.

According to social psychologist G. A. Fine:

The examination of rumour reaches the heart of what it means to have a public sphere, a space of common discourse in which a community collectively judges whether truth claims are to be accepted and responded to [...]. Rumour both derives from and contributes to the social organization of trust. ${ }^{3}$

Fine points out that the mere existence of rumours indicates a breach of trust in official institutions, but also suggests some confidence in fellow citizens, or more accurately, in the informal and often anonymous channels through which rumours flow.

In reality however, attitudes, both outwardly but probably also internal, towards unverified reports vary. In addition to those who are adamantly convinced of the truthfulness of the information they are sharing, there is a broader group showing hesitation. Messages are usually passed on with caveats like, "I'm not certain if it's true" or "you'll have to form your own opinion". This is typical of rumours spread by known sources, as the content we offer to our closer circle of acquaintances directly impacts our personal reputation. Belief in rumours, conspiracy theories and gossip tends to stem from a variety of factors, mainly personally acquired knowledge and experience, but also a level of trust in the sources or the authorities mentioned. Trust towards the prevailing social atmosphere is also important, which can collectively influence shared feelings of anxiety, distrust or enthusiasm, and can have an effect on the rationality of our judgments.

During the Second World War, psychologist Robert H. Knapp devoted himself to research on rumours during times of war. ${ }^{4} \mathrm{He}$ started with a theory that rumours, like folklore, mythology or humour, provide members of a community with emotional satisfaction, serving a similar function to dreams and fantasies in fulfilling the personal desires of individuals. Knapp justified the fact that the spreading of rumours is more intense during wartime than in peacetime in part by censorship, which encourages a hunger for information, but also by the strong emotional toll that battles take on the population. As the basis for his analysis,

2 Particularly in the case of allegations around perfectly functioning global conspiracies lasting decades or centuries, or in cases of statements denying basic scientific knowledge.

3 FINE, Gary A. Rumor, Trust and Civil Society: Collective Memory and Cultures of Judgement. In Diogenes, 2007, Vol. 213, No. 1, pp. 6-7.

4 KNAPP, Robert H. A Psychology of Rumor. In Public Opinion Quarterly, 1944, Vol. 8, No. 1, pp. $22-37$. 
he used a survey conducted by the Massachusetts Committee on Public Safety in September 1942 with the assistance of a public call mediated by publisher Reader's Digest. Knapp collected 1,089 rumours and divided them into categories based on the type of emotion that the rumour evokes. He created three basic groups: 1. The "Pipedream" or Wish Rumour, 2. The "Bogie" Rumour, and 3. The "Wedge-driving" or Aggression Rumour - the primary motivation being aggression or hatred. He determined that the greatest number of rumours came from the last group, and that these allegations especially implicated one's own party or allies, ${ }^{5}$ which in Knapp's opinion, contributed to division and a weakening of loyalty. Too many wedge-driving rumours can be the first signs of a scapegoat mentality. These conclusions are inspiring in many ways, suggesting that in times of danger there is likely a very strong tendency in society to search for culprits within its own ranks.

In contrast to rumours spread spontaneously, controlled propaganda and misinformation, or deliberately spread false reports, aim to purposefully influence public opinion. Propaganda can be characterised as:

The dissemination of information - facts, arguments, rumours, half-truths, or lies - to influence public opinion. Deliberateness and a relatively heavy emphasis on manipulation distinguish propaganda from casual conversation or the free and easy exchange of ideas." ${ }^{\prime 6}$

At its origin stands a specific group intending to utilise such fabrications as a means of achieving political and ideological goals.

The attraction to rumours and their impact on public opinion has been known for a long time. Both domestic and international power disputes were won not only through physical fighting with material weapons, but also thanks to an ability to disorient opponents and influence the mood of their armies and populations. Understanding the mechanisms proliferating the natural spread of rumours is also inspiring for the machinery of propaganda and disinformation. In times of danger, news about agitators and enemies hidden amongst one's own ranks is a powerful catalyst. The primary goal is to release information in such a way as to gain the public's trust. The public must then adopt it ideologically, identify with the message and act on it. What is important is that the recipients' trust is gained by confirming existing convictions, stereotypes, moral or ideological clichés, etc. Former Czech intelligence officer and State Security agent Ladislav Bittman (who later lectured at Boston University after emigration) emphasised the role of self-deception when describing prerequisites for the success of disinformation campaigns:

Self-deception is a very important psychological factor in disinformation mechanisms. The perpetrator consciously tries to get the victim to the point of being caught in the fraud by using language and arguments that are in line with his or her prejudices and moods. ${ }^{7}$

5 Of interest is Knapp's footnote that surprisingly few rumours contained anti-Russian content, (0.6\%) (KNAPP 1944, p. 26).

6 SMITH, Bruce L. Propaganda. In Encyclopoedia Britannica, 2016, https://www.britannica.com/topic/propaganda [last viewed on 11 October 2021]. This definition of propaganda comes from the Institute for Propaganda Analysis inspired by Harold Laswell as "the expression of opinions or actions carried out deliberately by individuals or groups with a view towards influencing the opinions or actions of other individuals or groups for predetermined ends and through psychological manipulations.” KELLEN, Konrad. Introduction by Konrad Kellen. In ELLUL, Jacques (ed.) Propaganda: The Formation of Men's Attitudes. Translated from French by Konrad Kellen and Jean Lerner. New York : Vintage Books, 1973, p. xi-xii.

7 BITTMAN, Ladislav. Mezinárodní dezinformace, černá propaganda, aktivní opatření a tajné akce. Praha : Mladá fronta, 2000, p. 29. 
This means strengthening the distrust and fear towards those whom the propaganda labels as a political enemy, and conversely, bolstering trust and loyalty towards those who are in the position of protector or liberator.

The Cold War period maintained an atmosphere of constant preparation for military conflict accompanied by intense propaganda as well as the spontaneous spread of suspicion of war preparations or possible "Trojan horses" and infiltration by enemy agents. This was true for both sides during the conflict. Periods of normal tension alternated with times of crisis threatened by open war and signals of retaliation.

In this article, some relatively well-known conspiracy theories that were conceived for the purposes of internal and foreign political propaganda are analysed. These are classic parables that became symbols of the start of the Cold War. Historical experience indicates that conspiracy theories spread both in liberal democracies embracing freedom of the press as well as dictatorships with systematic censorship. They are an integral part of political rhetoric, reacting to or taking advantage of universal human concerns about threats to life, health, property, or moral and religious values and traditions.

The crisis of trust between the world's superpowers battling for post-war spheres of influence was a direct effort to gain the loyalty of their own citizens by emphasising the impending sense of danger and vulnerability. Aside from news channels, a politically motivated fear of both external and internal enemies spread to the artefacts of popular culture. What kind of impact this had on informal, word-of-mouth communication is difficult to reconstruct today. The focus here will remain on the question of what parallels can be found in the spread, defence or questioning of known conspiracy theories regarding both internal and external enemies in the early stages of the Cold War on both sides. Research is based on period news and popular sources, as well as expert knowledge on political rumours and conspiracy theories.

\section{The Great Red Scare in the USA}

The term "Red Scare" originally signified a fear about the growing number and influence of communism and anarchism supporters in the period after the First World War. By the end of the 1950s, fears of Soviet agents operating through branches of the Communist Party in the USA were recast into an atmosphere of the "Great Red Scare" or the "Second Red Scare", or simply "McCarthyism" after Senator Joseph McCarthy. Suspicions of sinister activities by communist agents were publicised in the first years after the end of the Second World War leading to preventive legal measures. ${ }^{8}$

Katharina Thalmann, an expert in American studies, focuses on the change in standing of conspiracy theories from legitimate to illegitimate knowledge, which in the opinion of several authors, was rooted in the disproportionate reaction to fears of a communist conspiracy at the start of the Cold War. Thalmann provides several examples from popular culture in the form of propaganda illustrations by the communist conspiracy in the United States. ${ }^{9}$

8 The most significant was Executive Order 9835 by President Harry S. Truman, which for the first time introduced a review of the loyalty of government officials to prevent communist agents from acting in a government administration, National Archives, https://www.archives.gov/federal-register/executive-orders/1947.html [last viewed on 11 October 2021].

9 THALMANN, Katharina. The Stigmatization of Conspiracy Theory Since the 1950s. "A Plot to Make us Look Foolish". New York : Routledge, 2019, pp. 80-94. 


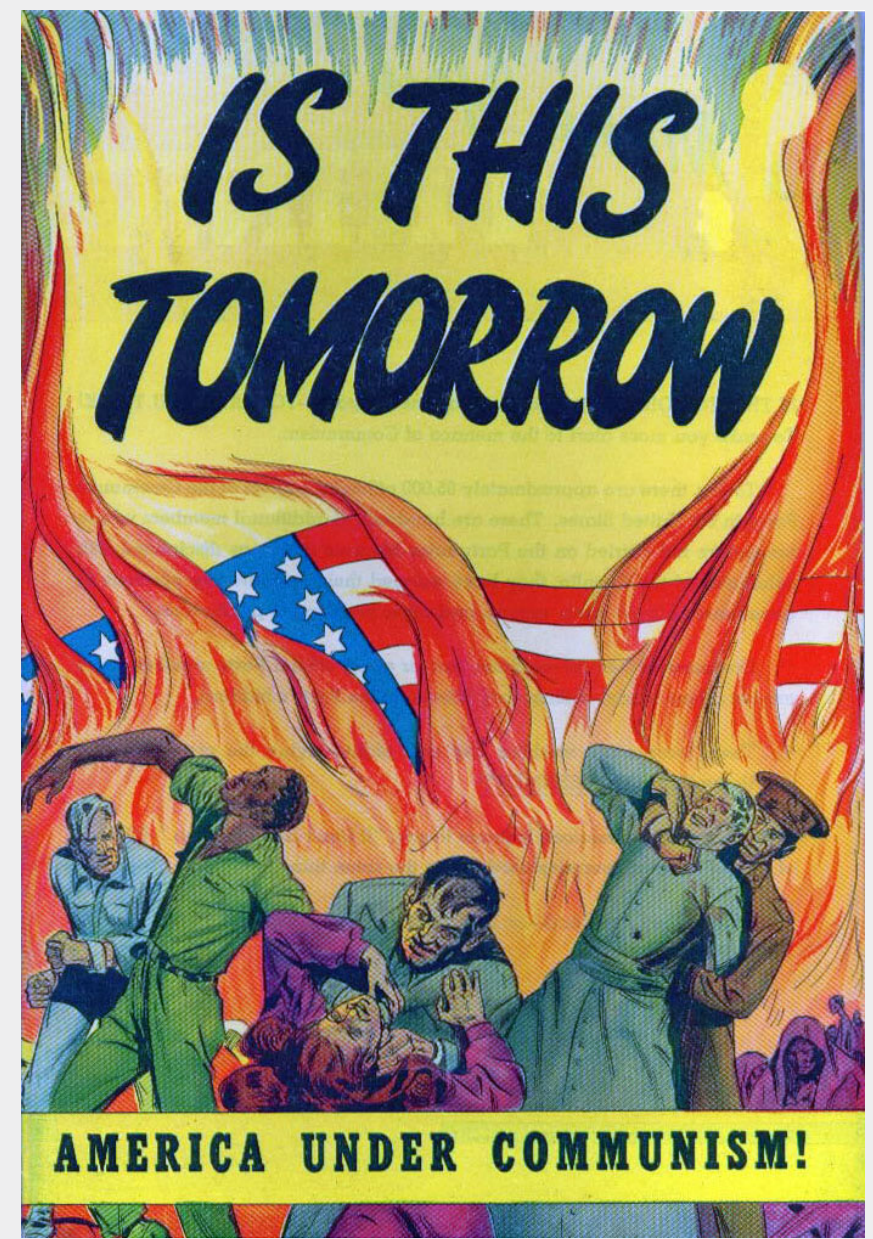

Image 1. Cover of the anti-communist propaganda comic book Is This Tomorrow. Source: Wikimedia Commons.
One such anti-communist comic, published in 1947, is called Is This Tomorrow. America Under Communism! ${ }^{10}$

The preface claims that there are 85 thousand official members of the Communist Party in the USA. The identity of further members is unknown because they are part of the fifth column of the Kremlin and "they have wormed their way into key positions in government offices, trade unions, and other positions of public trust." ${ }^{11}$

Based on a fictional retrospective narrative of members of the Communist Party, the pamphlet reveals the strategies by which the Communists came to power in the USA, claiming they took advantage of the economic crisis and under the pretext of creating a front against fascism or intolerance, succeeded in gaining support of the media as well as some famous names. It further states that while a social crisis was provoked by sowing religious, racial and class divisions, the country was hit by a wave of strikes and the unions helped Communists seize power. Rigged elections followed, as did the transport of inconvenient people to labour camps, the confiscation of property, censorship and the spread of propaganda in schools, resulting in children reporting parents to agents of the Kremlin. ${ }^{12} \mathrm{~A}$ single year was enough for the Communists to obtain power. In conclusion, the pamphlet emphasises that the Communists utilised the same methods to rise to power in other countries: "It happened in Poland, Hungary, Yugoslavia, and country after country, the world over. It is their plan for America." The reader is ultimately called upon to take personal responsibility in the fight against the Communists. $\mathrm{He} /$ she must know their methods, because "you are the one with whom the Communist is struggling right now."'13

10 Four million copies were published by a church community. Some were intended for sale, but the rest were distributed free of charge to the public and other church groups. MURRAY, Chris. Cold War. In BOOKER, M. Keith (ed.) Encyclopedia of Comic Books and Graphic Novels. Vol. 1, Santa Barbara : Greenwood, 2010, pp. 104-109, https://pdfhive.com/wp-content/uploads/2019/04/Encyclopedia-of-Comic-Books-and-Graphic-Novels-PDFhive.com-.pdf [last viewed on 11 October 2021]

11 Is This Tomorrow 1947.

12 It is possible that the propagandist story of the Soviet children's "martyr" Pavel T. Morozov was the inspiration. According to Soviet literature, thirteen-year-old "Pavlik" Morozov betrayed his father's office for hiding grain subject to forced purchase and his grandfather killed him in revenge. The story was produced in various media, intended to encourage the devotion of children and young people to the beliefs of communist ideology, which should be superior to family ties. The murder of P. T. Morozov (1918-1932) actually happened, but its truth was far from this contrived story. KELLY, Catriona. Comrade Pavlik: The Rise and Fall of a Soviet Boy Hero. London : Granta Books, 2005.

13 Is This Tomorrow, 1947. 
The loudest and most visible rhetoric came from Wisconsin Senator Joseph McCarthy, who sounded the alarm against an unseen network of communist conspirators undermining the United States from all sides - in economics, politics, the military, culture and health - personifying the "Great Red Scare". He delivered a shocking speech on 9 February 1950, warning against homegrown traitors: "While I cannot take the time to name all the men in the State Department who have been named as members of the Communist Party and members of a spy ring, I have here in my hand a list of $205{ }^{\prime 14}$ In a speech on 14 June 1951, he named US Secretary of State George C. Marshall as the central figure of the conspiracy, and cautioned:

How can we account for our present situation unless we believe that men high in this Government are concerting to deliver us to disaster? This must be the product of a great conspiracy, a conspiracy on a scale so immense as to dwarf any previous such venture in the history of man. A conspiracy of infamy so black that, when it is finally exposed, its principals shall be forever deserving of the maledictions of all honest men. [...] What can be made of this unbroken series of decisions and acts contributing to the strategy of defeat? They cannot be attributed to incompetence. [...] What is the objective of the great conspiracy? I think it is clear from what has occurred and is now occurring: to diminish the United States in world affairs, to weaken us militarily, to confuse our spirit with talk of surrender in the Far East and to impair our will to resist evil. To what end? To the end that we shall be contained, frustrated and finally: fall victim to Soviet intrigue from within and Russian military might from without. ${ }^{15}$

The goal of Communists infiltrating into state administration was said to be the rise of the Soviets over the United States. ${ }^{16}$ Anti-communist rhetoric of the 1950s in the United States greatly emphasised key elements of American democracy and stressed individuality in comparison with Soviet totalitarianism. Fears of a communist conspiracy, however, ultimately led state representatives to violate the personal rights they were supposed to protect.

Worries of pro-Soviet agents in the USA were not entirely unfounded. Research into Soviet archives in the 1990s showed that the Communist Party of the USA (CPUSA) did receive financial support directly from Moscow, from its founding in 1919 until 1989, ${ }^{17}$ and its members also engaged in espionage. Communist ideology attracted a quite a broad demographic of US citizens, including scientists, officials and artists. ${ }^{18}$

The problem with spreading a fear of communists lay especially in the difficulty of identification. According to then Attorney General J. Howard McGrath, the communist was "everywhere - in factories, offices, butcher shops, on street corners, in private businesses each carries with him the germs of death."19 Thus, anyone could be labelled a communist,

14 “Communists in Government Service," McCarthy Says. United States Senate, 9 February 1950. https://www.senate. gov/about/powers-procedures/investigations/mccarthy-hearings/communists-in-government-service.htm [last viewed on 11 October 2021]

15 Speech delivered by Senator Joseph McCarthy before the Senate on 14 June 1951. Modern History Sourcebook: Senator Joseph McCarthy: The History of George Catlett Marshall, 1951. https://sourcebooks.fordham.edu/ mod/1951mccarthy-marshall.asp [last viewed on 11 October 2021]

16 More about this in SCHRECKER, Elle. The Age of McCarthyism: A Brief History with Documents. 2nd ed. Boston : Bedford, 2002, pp. 240-41. Cit. after THALMANN 2019, p. 43.

17 KLEHR, Harvey - HAYNES, John Earl -ANDERSON, Kyrill M. The Soviet World of American Communism. New Haven : Yale University Press, 1989, pp. 74, 148; BITTMAN 2000, p. 53.

18 PIPES, Daniel. Spiknutí. Názory a teorie. Z anglického originálu preložila Daria Dvořáková. Praha : Themis, 2003, p. 143.

19 KNIGHT, Peter. Conspiracy Culture. From Kennedy to the X Files. London; New York : Routledge, 2000, p. 169. 
and the communist conspiracy could be anything that upset public opinion. The rhetoric of disseminating fear employed a metaphor of an attack on the "body" of American politics by comparing communism to an infection and parasites. ${ }^{20} \mathrm{McC}$ arthy's frequent, ill-founded allegations, which cost people their jobs and reputations, and his clear abuse of the fear of communists used specifically to eliminate political opponents brought increasingly negative reactions from his own supporters. As a result, people became aware of the use of conspiracy theories in a pejorative and pathological way. A well-known report by American historian Richard Hofstadter in 1964 explains the "paranoid style" - the equivalent effect of conspiracy theories - using one of Senator McCarthy's anti-communist speeches as an example. Hofstadter's thesis was that “The paranoid style is an old and recurrent phenomenon in our public life which has been frequently linked with movements of suspicious discontent." ${ }^{21}$ In his opinion, the feeling of being deprived of ownership of America was unique to the paranoid style of the modern right. Old American virtues were supposedly destroyed by cosmopolitans and intellectuals, while capitalism was being dismantled by socialists and communists. Thus, outsiders or foreigners were no longer the only suspected conspirators, but people in the highest places. ${ }^{22}$

\section{Fluoride in the Drinking Water in the USA as a Communist Conspiracy}

A panicked warning about the ubiquity of the communist conspiracy in the United States came in the form of campaigns against fluoridation, the addition of fluoride to drinking water to reduce tooth decay. This time, the fear of communists was associated with public anxiety over the consequences of the mass use of chemicals. Robert J. Johnston describes how in the 1950s, public health and dentistry experts in favour of fluoridation were shocked by the reaction of groups fighting against their efforts. They were unable to comprehend the counter-reasoning and could not stop the anti-fluoridation campaigns, which found success with voters as well as local politicians. This was due to the ability of campaign spokespersons to link the fluoridation of water to political and social issues in the United States. ${ }^{23}$ The potential negative effects of fluoride on human health or the environment were useful arguments, but religious and political reasons were equally important. Opponents of fluoridation among conservatives noted a restriction of individual freedom in the process and saw fluoridation as a prelude to more serious programmes, such as birth control or control of people's minds. Some conservatives were even convinced that fluoridation was a communist conspiracy to destroy America, that the fluoride was intended to be a means of killing or paralysing millions of Americans enabling a Soviet invasion. Similar positions were taken not only by lay people, but by some doctors too, such as Dr. Charles Betts, a dentist from Ohio who also fought against vaccinations and the pasteurisation of food. He claimed that fluoridation was being promoted by the aluminium industry, which he said was in the service of the communists. In his view, fluoridation should be "better than using the atom bomb because the atom bomb has to be made, has to be transported to the place

20 KNIGHT 2000.

21 HOFSTADTER, Richard. The Paranoid Style in American Politics. In Harper's Magazine, November 1964, pp. 77-78.

22 HOFSTADTER 1964, p. 81.

23 JOHNSTON, Robert D. The Politics of Healing. New York; London : Routledge, 2004, p. 132. 


\section{It the Sign of THE UNHOLY THREE}

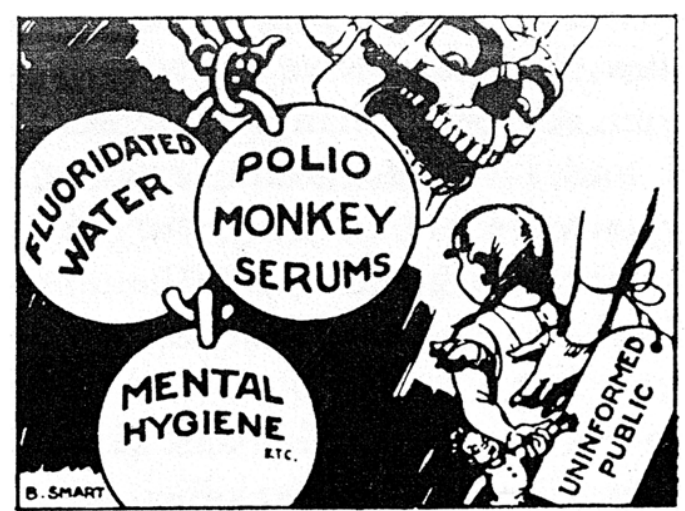

Are you willing to PIT IN P.AWN to the INHOI.Y THRF.F all of the material, mental and spiritual rewiurces of this (iREAT REPIBI.IC:

FLUORIDATED WATER

1-Water containing Fluorine (rat poison - nn antidotel is already the only water in many of our army camps, making it very casy for saboteurs to wipe out an entire camp personel. If this happens, every

\section{POLIO SERUM}

2-Polio Serum, it is reported, has alrcady killed and maimed children; its future effect on minds and bodies cannot be guaged. This vaccine drive is the entering wedge for nation-wide socialized medicine, by the U.S. Public Health Service, (heavily infiltrated by Russian-born doctors, according to Congressman Clare Hofrman.) In enemy hands it can destroy a whole generation.

\section{MENTAL HYGIENE} 3-Mental Hygiene is a subtle and diabolical plan of the enemy
to transform a free and intelligent people into a cringing horde of zombies.

Rabbi Spitz in the American Hebrew. March 1, 1946: "American Jews must come to grins with our contemporary anti. Semites; we must fil our insane asylums with anti-Semitic lunatics."

FIGHT COMMUNISTIC WORID GOVERNMENT hy destroying THE CNHOLY THREE !!! It is later than you think!

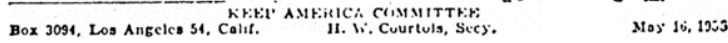

Image 2. "At the Sign of the UNHOLY THREE", a flier issued in the 1950s-60s to promote hygiene as an anti-communist goal. Source: Wikimedia Commons. it is to be set off while poisonous fluorine has been placed right beside the water supplies by the Americans themselves ready to be dumped into the water mains whenever a Communist desires!"24

\section{Fears of a Third World War in Cze- choslovakia after 1948}

The communist coup in 1948 meant a definitive incorporation of Czechoslovakia into the Soviet sphere of influence, which also meant adopting Soviet propaganda methods for political influence. Several authors have pointed out similarities between Hitler and Stalin's propaganda, exploiting accusations of imaginary conspiracies in order to strengthen power and legalise violence. The state terrorism of German Nazism and Soviet Stalinism was born directly from theories of international conspiracy against the regimes. ${ }^{25}$ Freedom of the press in socialist dictatorships was limited by censorship, which concealed or ignored selected information or on the contrary, altered or direct-

ly fabricated information based on the needs of the government. Public awareness of such intense, state-controlled censorship also had the opposite effect, however, which supported the resonance of unofficially spread rumours, suspicions and alternative interpretations of official press releases. ${ }^{26}$ In communist Czechoslovakia, developing a climate of fear around the activity of class enemies, both internal and external, became an integral part of state propaganda used to legitimise political reprisals. The misuse of this tactic politically was permissible mainly by the ambiguity of the term "class enemy", which could be taken to mean practically anyone. ${ }^{27}$ Propaganda hysteria in Czechoslovakia escalated in the form of political "monster trials" against supposedly

24 JOHNSTON 2004, p. 137

25 See, for example, TUCKER, Robert C. Stalin in Power: The Revolution from Above, 1928-1941. New York: Norton, 1990, p. 591.

26 For more detail, see ZAVACKÁ, Marína. Whispered Rumor as a Kind of Independent Political News Service in Slovakia in 1953: People and State Reacting to the Death of J. V. Stalin and Klement Gottwald. In Slovak Contributions to the 19th International Congress of Historical Sciences. Bratislava: Veda; Historický ústav SAV, 2000, pp. 229-240; ZAVACKÁ, Marína. A čo písuu, bude vojna? Propagandistické využívanie pocitu ohrozenia v studenej vojne. In ŠTEFANSKÝ, Michal - PURDEK, Imrich (eds.) Slovensko vo vojnách a v konfliktoch $v$ 20. storočí. Bratislava : Vojenský historický ústav, 2003, pp. 233-238; ZAVACKÁ, Marína. Kto žije za ostnatým drôtom? Oficiálna zahraničnopolitická propaganda na Slovensku 1956 - 1962: teórie, politické smernice a spoločenská prax. Bratislava : Veda, 2005.

27 VESELSKÁ, Natália. Strach - nástroj moci. Manipulovatelnost’ spoločnosti počas komunistického režimu. In BYSTRICKÝ, Valerián - ROGULOVÁ, Jaroslava (eds.) Storočie propagandy. Bratislava : AEP, 2005, p. 182. 


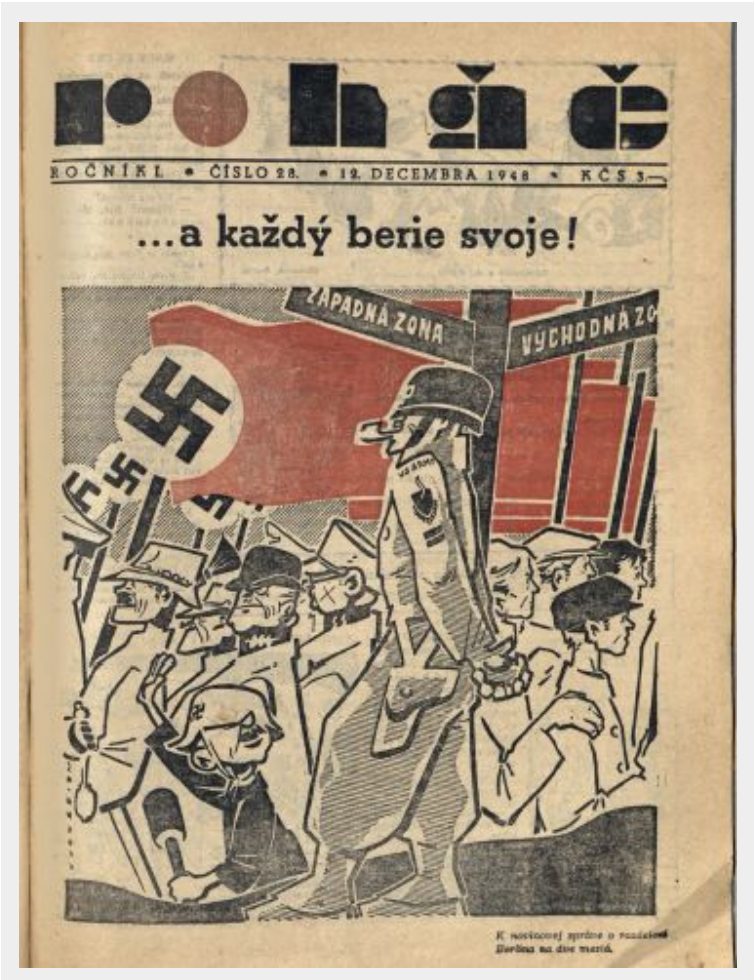

Image 3. Viliam Weisskopf: “...and everyone takes its own! On the newspaper report on the division of Berlin into two cities." [Figures with attributes of Nazism and militarism go to the "western zone" and peaceful citizens to the "eastern zone"]. In Roháč, 6 December 1948. Source: Author's archive. anti-state conspirators and collaborators from the West. ${ }^{28}$

The media also supported the creation of a polarised world by emphasising the moral differences of the West and the East. In the post-war image of the West, embodied mainly by the United States, violence, debauchery, military harassment and social injustice were accentuated. ${ }^{29}$ Militarism was characterised in communist propaganda as directly linked to German Nazism, another feature highlighted in their projected image of the West. In the words of Andrej Švec, author of a publication on political caricature in Slovakia, Slovak foreign policy after the end of the Second World War created "a series of strong and concentrated attacks on representatives of imperialism, prosecuted political representatives of West Germany, revealing their hereditary relationship with Hitler... and pointed to the militaristic face of Western democracy." ${ }^{30}$ Viliam Weisskopf, for example, was an important creator of Slovak foreign policy caricature of this time, working in the magazine Roháč.

\section{The Colorado Potato Beetle - A Symbol of Eastern Propaganda in the 1950s}

Constant suspicion of a potential "Trojan horse" infiltrated by an enemy agent at this time led to a conspiracy theory about the Colorado potato beetle, popularly called the "mandelinka" in Czechoslovakia. The pest arrived in western Europe from the American continent for the first time in the second half of the 19th century in potato shipments. Waves of infestations occurred in France during the First World War and then in Germany in the mid-1930s. The Slovak press even issued warnings about the possible introduction of the potato beetle into local fields at the end of the 1930s, urging people to report every occurrence to the authorities. ${ }^{31}$ In 1946, the Czechoslovak press again highlighted the presence of the potato beetle in the fields of Austria, noting it was thus only a matter of time before the nuisance crossed the Czechoslovak border. In 1950, when the beetle population massively exploded in the German Democratic Republic (GDR), Czechoslovakia and Poland, an atmosphere of heightened tensions between the

28 The most famous was the proceedings against Milada Horáková.

29 PANCZOVÁ, Zuzana. The Image of the West in Conspiracy Theories in Slovakia and its Historical Context. In Electronic Journal of Folklore, 2017, Vol. 22, No. 3, p. 61-62.

30 ŠVEC, Andrej. Bič smiechu. Politická karikatúra na Slovensku (1861 - 1985). Bratislava : Tatran, 1988 , p. 86.

31 Pohotovost' proti mandelinke zemiakovej. In Slovenský hlas, 10 December 1938, p. 8; Boj proti mandelinke zemiakovej. In Slovák, 30 September 1941, p. 8. 
USA and the USSR justified more propaganda. Eyewitness reports of American planes were found in the GDR and the local Minister of Agriculture, Paul Mercker, officially accused the USA of releasing potato beetles in Europe. The Czechoslovak government joined in, issuing a statement on 28 June 1950 asserting:

Boxes and flasks filled with this beetle were also found. All this is irrefutable proof that the current mandelinka danger could not have occurred in a natural and usual way, but that this dangerous pest was brought to us artificially, intentionally and en masse using the clouds and winds by the Western imperialists, as well as by their destructive agents sent to us. ${ }^{32}$

The notion that the outbreak in Central Europe was caused by dropping beetles from American planes was, according to contemporary observers, absurd for many people, but it had a lot of support in a massive media campaign. The beetle was colourfully depicted as an insatiable imperialist "American beetle" and a "Wall Street parasite". The appropriate antithesis to the malicious Western planes in propaganda rhetoric was the USSR's airborne reinforcements, which protected socialist agriculture by spraying $\mathrm{DDT}^{33}$ Soviet sources were the inspiration for press campaigns in Czechoslovakia and Soviet articles on this topic were often quoted in their entirety. On 29 July 1950, the magazine Týždeñ (The Week) published an article entitled, "Literaturnaja gazeta o šestinohom poslovi Wal Streetu" [Literature gazette on Wall Street's six-legged messenger], interpreting an article by writer Gennady Fish who claimed that the USA had sent seeds infected with harmful insects and other pests to the USSR during both the Second World War and as part of the 1946 United Nations Relief and Rehabilitation Administration international operation. ${ }^{34}$

In addition to printed news, the scandal of the "American Beetle" was also communicated to the general public in Czechoslovakia through leaflets and documentary films. Aside from the illustrated agitprop for children, O zlém brouku bramborouku (1950)

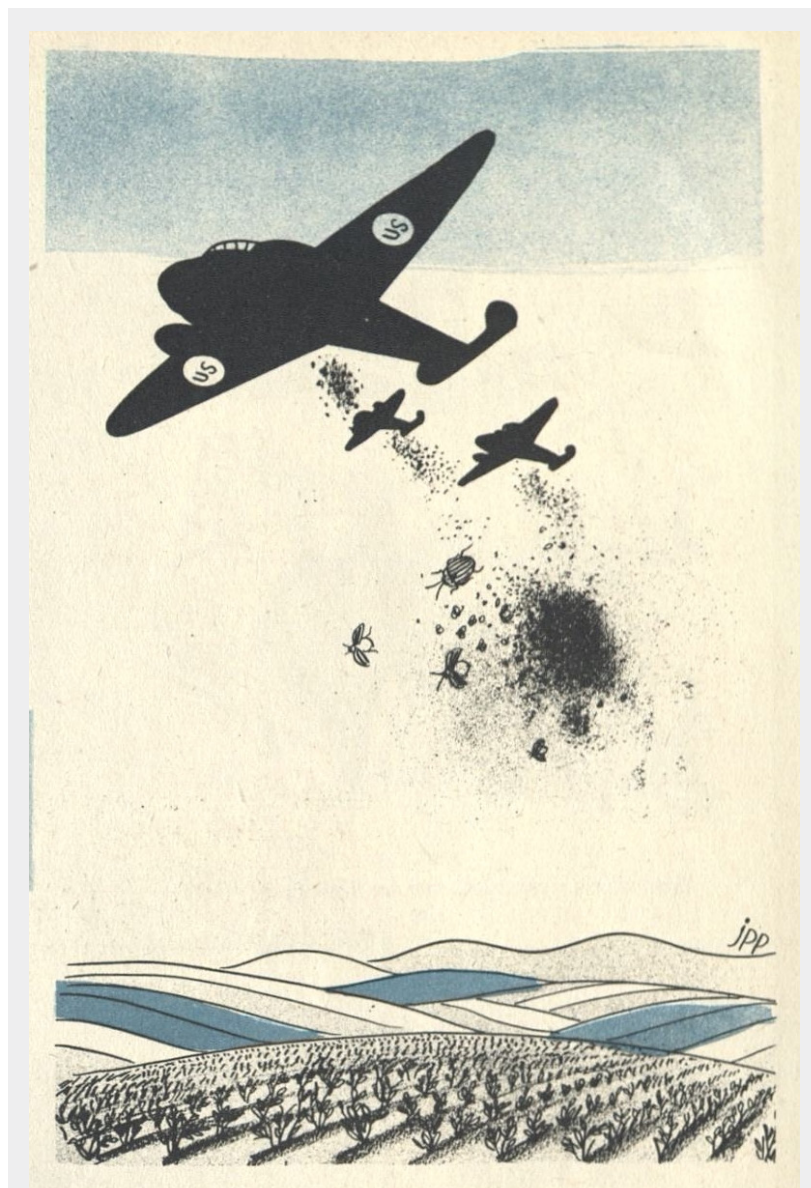

Image 4. US planes drop potato beetles over socialist fields. In Roháć 11 June 1950. Source: Author's archive.

32 Provolání vlády k boji proti mandelince bramborové. In Rudé právo, 29 June 1950, p. 1.

33 For example: Sovietski letci pomáhajú nám ničit amerického chrobáka. Reportážne zábery so sovietskym poručíkom letectva Petrom Michajlovičom Ossipovom. In Týždeň, 14 July 1951, Vol. 6, No. 28 , p. 7.

34 Literaturnaja gazeta o šestinohom poslovi Wall Streetu. In Týždeň, 29 July 1950, Vol. 5, No. 30, p. 4. 
[About the Evil Potato Beetle], ${ }^{35}$ a short film was made called Mandelinka bramborová (1950) [The Potato Mandelinka], which described the details of "the most recent criminal tool of American barbarism", and a year later, Boj proti mandelince bramborové (1951) [Fight against the Potato Beetle] was produced about the aid provided by Soviet pilots to Czechoslovak farmers. Accusations of the deliberate distribution of the beetle by Western capitalists, however, had appeared in an educational film documentary about the insect entitled Škudce [Pest] as early as 1949, the production of which was commissioned to the Czechoslovak state film company by the Ministry of Agriculture. It even won a National Prize in 1950 for the production an important popular science film. ${ }^{36}$ Movements condemning the attack of the American imperialists also included the "spontaneous" distribution of outraged civic resolutions. ${ }^{37}$

It is difficult today to recreate how convincing this campaign was for the public at the time. It likely depended to a great extent on one's loyalty to communist ideology, however, several contemporary observers admit in their memoirs the possibility that airborne paratroopers coordinated by the United States were responsible for the excessive reproduction of the potato beetle. One of them acknowledged its veracity with respect to other similar cases of aviation diversionary activity from the West. This was specifically about releasing balloons with propaganda flyers from West Germany, organised by the National Committee for a Free Europe - events like the Winds of Freedom (1951), Prospero (1953) and Veto (1954). ${ }^{38}$ It is also possible to find similar arguments in online discussions of related articles.

Deliberation of the possible use of a beetle to destroy an enemy country's crops surfaced in France during the First World War. During the Second World War, the Germans suspected that the Allies would use the beetle as a biological weapon. This was the impetus for conducting experiments to confirm whether such a biological attack would even be possible and whether it could be used in the United Kingdom. For these purposes, a special "Kartoffelkäferforschungsinstitut" [Potato Beetle Research Institute] was even set up to test the success of dropping beetles from an aircraft. ${ }^{39}$

Though the Central European scandal around the beetle was not resolved by any clear proof of Western sabotage and today generates more laughter than anything else, there is a parallel with similar accusations of the use of biological weapons in the Korean War (1950-1953). The cases are related not only in terms of timing, but also propaganda. There, the campaign against the potato beetle began three days after the North Korean army invaded South Korea. In the scope of war propaganda, the United States

35 Children were encouraged to collect potato beetles as part of mass brigades: "Oh, if they could only destroy all our potato crops. They would rejoice: 'We have fulfilled the task given to us by the lords of the West. There will be no potatoes in the Czechoslovak Republic!' No, we won't! Entire expeditions of children will go to save our harvest. They will inspect all the potato bushes from below to see if they can find eggs on the back of the leaves." SEKORA, Ondřej. O zlém brouku Bramborouku. O mandelince bramborové, která chce loupit $z$ našich talírů. Praha : Státní nakladatelství dětské knihy, 1950.

36 Filmový přehled, https://www.filmovyprehled.cz/cs/film/401661/skudc [last viewed on 11 October 2021]

37 A detailed description of the campaign to combat the beetle in Czechoslovakia is given by the study FORMÁNKOVÁ, Pavlína. Kampaň proti „americkému brouku“ a její politické souvislosti. In Pamět a dějiny, 2008, Vol. 2, No. 1, p. 22-38. https://www.ustrcr.cz/data/pdf/pamet-dejiny/0801-22-38.pdf [last viewed on 11 October 2021]

38 TOMEK, Prokop. Balony svobody: letákové operace Svobodné Evropy 1951-1956. Cheb : Svět křídel, 2014.

39 GARRETT, Benjamin C. The Colorado Potato Beetle Goes to War. In Chemical Weapons Convention Bulletin 33, September 1996, Historical Note no. 2, p. 2-3. http://www.sussex.ac.uk/Units/spru/hsp/documents/CWCB33-Garrett.pdf [last viewed on 11 October 2021] 
was accused of spreading a biological disease by dropping infected insects into Korean territory. The first, vague allegations were made by North Korea and China as early as 1951. China and North Korea also accused the US of spreading infection at the beginning of 1952, when outbreaks of smallpox, cholera and plague occurred among members of the Chinese volunteer army fighting for North Korea. These allegations were confirmed by captured US pilots, who later revoked their statements claiming they were forced and a result of torture. Research in Soviet archives in the 1990s, published by Kathryn Weathersby and Milton Leitenberg as part of the International History Project at the Woodrow Wilson Center in Washington, supports statements that the accusations against the USA by North Korea, China and the USSR were a planned disinformation campaign. ${ }^{40}$

\section{Conclusion}

The competition for military, economic and moral superiority over combatants on opposite sides of the Iron Curtain through the abundant use of propaganda lasted for four decades and we are still feeling the reverberations today. Conspiracy theories as an element of propaganda mirrored fears about the real threat of another global conflict, but they were also a tool used to legitimise current government power. Employed at the beginning of the Cold War, they were evidence of the climate of fear over a new war. The result was a wave of propaganda-based scapegoating and the promotion of conspiracies in countries with strong traditions of liberal democracy, though also within the environments of censorship-controlled dictatorships. Propaganda sought to gain trust by stoking normal human fears about threats to life, health, property or morals. In the case of the Cold War, this brought on a revival of the simplified and often stereotyped polarized image of the world typical for propaganda in a "hot" war conflict. The crisis of trust between superpowers sharing post-war spheres of influence was linked to efforts to gain the loyalty of citizens by emphasising a sense of danger. An important element was also that in addition to fabricated, exaggerated or unsubstantiated claims, conspiracy theories contained information about genuine threats; the real existence of Soviet agents in the USA, the real threat of exaggerated chemical attacks, existing experiments with biological weapons, etc. The eventual fate of the aforementioned propaganda activities is also interesting. In the case of the hunt for communists in the USA, under the influence of the free press and pressure from academic and political elites, there was a reflective response against the misuse of conspiracy theories. Similar public criticism was not expressed in communist regimes.

Impulsively spread politically based rumours, conspiracy theories, disinformation and propaganda are key components of political reality. Many established disinformation "tricks" have been repeated throughout history, others have been gradually improved

40 WEATHERSBY, Kathryn. Deceiving the Deceivers: Moscow, Beijing, Pyongyang, and the Allegations of Bacteriological Weapons Use in Korea. In Cold War International History Project. Bulletin 11, Winter 1998, p. 176-184. https://www.wilsoncenter.org/sites/default/files/media/documents/publication/CWIHP_Bulletin_11.pdf [last viewed on 11 October 2021]; LEITENBERG, Milton. New Russian Evidence on the Korean War Biological Warfare Allegations: Background and Analysis. In Cold War International History Project. Bulletin 11, Winter 1998, p. 185-199. https://www.wilsoncenter.org/sites/default/files/media/documents/ publication/CWIHP_Bulletin_11.pdf [last viewed on 11 October 2021] 
thanks to new knowledge. The current capabilities of the Internet present a significant accelerator for misinformation. Information was and will continue to be a strategic matter, and the control or free dissemination has been and will continue to be part of public debate and covert policies. There is no simple guide to reliably distinguishing true information from misinformation, but an awareness of propaganda campaigns from the past undoubtedly helps.

Cite:

PANCZOVÁ, Zuzana. Conspiracy Theories and Rumours as Key Elements of Political Propaganda: The Cold War in the USA and Czechoslovakia in the 1950s. In Forum Historiae, 2021, Vol. 15, No. 2, pp. 25-37. ISSN 1337-6861. DOI: https://doi.org/10.31577/forhist.2021.15.2.3

\section{Zuzana Panczová}

Ústav etnológie a sociálnej antropológie SAV

Klemensova 19

81364 Bratislava

email: zuzana.panczova@savba.sk

https://orcid.org/0000-0001-7822-8118 